\title{
PEMANFAATAN CONTAINER MENJADI RUANG ISOLASI APUNG SEBAGAI ALTERNATIF BAGI PASIEN COVID-19
}

Siti Dwi Lazuardi, Akhdan Muhammad Muaz, Dina Fatimatuz Zahroh, Altalariq Pranantha Yudha Airlangga, dan Afyfah Ramadhani Dias Saputri

Departemen Teknik Transportasi Laut dan Institut Teknologi Sepuluh Nopember Surabaya Jawa Timur, Indonesia

Email:dwilaz@gmail.com, akhdan99@gmail.com, fatimatuz.dina@gmail.com, altalariqpranantha@gmail.com,dan afy.ramadhanii@gmail.com.

\section{Abstract}

Until now, COVID-19 cases continue to increase, too many patients needing intensive care resulting in hospitals experiencing overloaded capacity conditions. In order to minimize the presence of independent care patients and the risk of family clusters, the use of containers becomes a floating isolation room as an alternative for the community to receive intensive COVID-19 treatment. Utilization of used 20 feet container combined with a base for floating made from HDPE (High-Density Polyethylene) and WPC (Wood Plastic Composite) footing. In considering the amount of costs and measuring the optimization of the benefits of the research, this research uses the CBA (Cost-Benefit Analysis) method and the BCR (Benefit Cost Ratio) method to test the feasibility of this research. The results showed that the use of used containers to be a floating isolation room was in the good category, where this study can reduce the number of self-isolating patients by $35 \%$ and the results of the calculation of the benefits have a ratio of 1.02 and produce a positive NPV value with eligibility limits, namely $B C R>1$, and $N P V>1$. From these results, it can be concluded that this floating isolation room is feasible to be realized or operated.

Keywords: COVID-19; HDPE; floating isolation room; WPC

\section{Abstrak}

Kasus COVID-19 hingga saat ini terus mengalami peningkatan, terlalu banyaknya pasien yang membutuhkan perawatan intensif mengakibatkan rumah sakit mengalami kondisi overloaded capacity. Dalam rangka meminimalisir adanya pasien rawat mandiri dan berisiko adanya cluster keluarga, maka pemanfaatan container menjadi ruang isolasi apung sebagai alternatif bagi masyarakat untuk mendapat penanganan intensif COVID-19. Pemanfaatan container bekas 20 feet dipadukan dengan alas untuk mengapung berbahan HDPE (High-Density Polyethylene) dan alas pijakan WPC (Wood Plastic Composite). Dalam mempertimbangkan besaran biaya serta mengukur keoptimalan dari manfaat penelitian, maka penilitian ini menggunakan metode CBA (Cost-Benefit Analysis) dan metode BCR (Benefit Cost Ratio) untuk menguji kelayakan dari penelitian ini. Hasil penelitian menunjukan bahwa pemanfaatan container bekas menjadi ruang isolasi apung termasuk dalam kategori baik, dimana penelitian ini dapat menekan angka pasien isolasi mandiri sebesar 35\% dan hasil perhitungan manfaat memiliki rasio sebesar 1,02 dan menghasilkan nilai NPV positif dengan batasan kelayakan yaitu BCR $>1$, dan NPV 
Siti Dwi Lazuardi, Akhdan Muhammad Muaz, Dina Fatimatuz Zahroh, Altalariq Pranantha Yudha Airlangga, dan Afyfah Ramadhani Dias Saputri

$>$ 1. Dari hasil penelitian tersebut, dapat disimpulkan bahwa, ruang isolasi apung ini layak untuk direalisasikan atau dioperasikan.

Kata kunci: covid-19; HDPE; ruang isolasi apung; WPC

\section{Pendahuluan}

Wabah corona virus disease 2019 (Covid-19) yang telah melanda 215 negara di dunia, memberikan tantangan tersendiri bagi lembaga pendidikan, khususnya Perguruan Tinggi. Untuk melawan Covid-19 Pemerintah telah melarang untuk berkerumun, pembatasan sosial (social distancing) dan menjaga jarak fisik (physical distancing), memakai masker dan selalu cuci tangan (Sadikin \& Hamidah, 2020).

Kondisi di dunia ini sedang tidak baik-baik saja. Hal tersebut dapat dijelaskan dengan menyebarnya satu wabah yang hampir seluruh dunia merasakan dampak dari perihal tersebut (Ningsih, Yandri, Sasferi, \& Juliawati, 2020), wabah yang dimaksud adalah COVID-19. Wabah ini sudah mulai menyebar luas sejak tahun 2019 dan akhirnya menyebar di Indonesia sejak akhir Januari 2020. Semakin lama, jumlah pasien COVID-19 di Indonesia, termasuk di Provinsi DKI Jakarta semakin meningkat (Corona.jakarta.go.id, Data Pemantauan Covid-19, 2020), yang dimana Provinsi DKI Jakarta merupakan salah satu kota yang memiliki jumlah penduduk yang ternilai padat. Berikut merupakan data penduduk Provinsi DKI Jakarta tahun 2015-2020 dalam tampilan grafik:

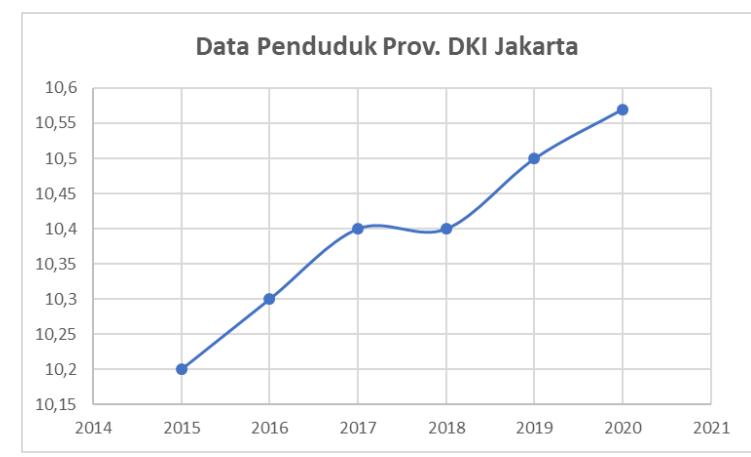

Gambar 1

Grafik Data Penduduk Provinsi DKI Jakarta 2015-2020

(Databoks, 2018) (databoks \& Jayani, D. H., 2019) (databoks, 2019)

Dengan diketahui jumlah data penduduk di Jakarta, pada penelitian ini mengambil salah satu sample data kenaikan jumlah kasus positif COVID-19 di Provinsi DKI Jakarta yaitu dengan mengambil data pasien positif COVID-19 pada bulan Oktober 2020. Data tersebut ditampilkan dalam bentuk grafik sebagai berikut: 


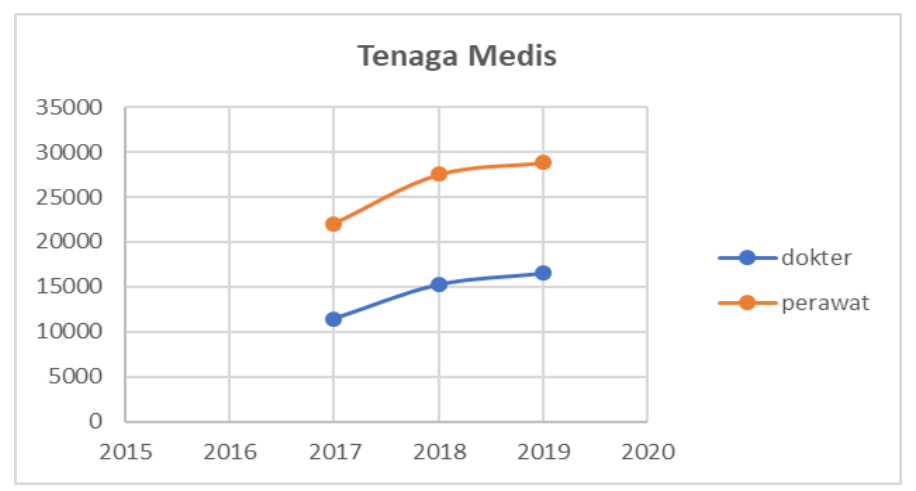

Gambar 2

Data Pasien Positif COVID-19 Bulan Oktober 2020

(Corona.jakarta.go.id, 2020)

Dapat terlihat bahwa jumlah positif COVID-19 meningkat, walaupun sempat mengalami penurunan, tetapi di akhir bulan kembali meningkat. Dengan begitu, tidak menutup kemungkinan bahwa rumah sakit dan tempat isolasi tidak dapat menampung $100 \%$ pasien positif COVID-19, begitu pula tenaga medis yang berjumlah minim, berpotensi tidak dapat menangani secara maksimal untuk pasien COVID-19 yang melakukan isolasi mandiri dirumah. Berikut merupakan data tenaga medis Provinsi DKI Jakarta range tahun 2017-2019:

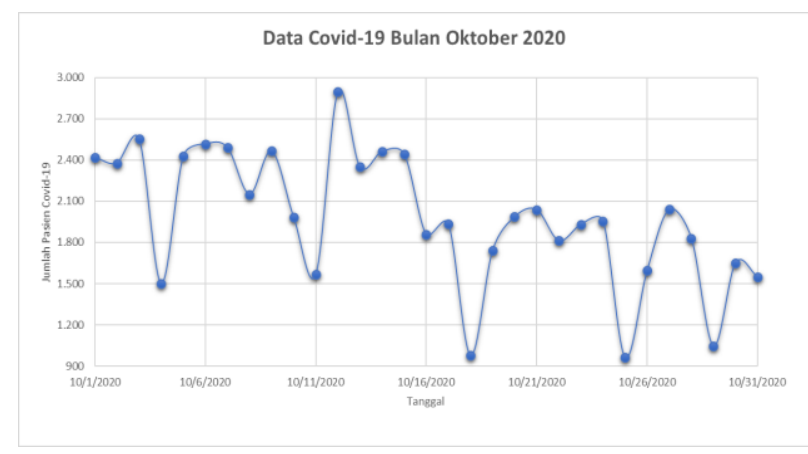

Gambar 3

Grafik Tenaga Medis Provinsi DKI Jakarta 2017-2019

(Kemkes.go.id, 2020)

Dapat terlihat bahwa jumlah tenaga medis yang terdiri dari dokter dan perawat di Jakarta mencapai 10.000-30.000 orang. Tetapi dalam perihal penanganan COVID-19 pada realitanya, tenaga medis yang ada di Jakarta tidak digunakan $100 \%$ dari jumlah yang ada, tenaga medis untuk penanganan COVID-19 harus diseleksi terlebih dahulu, dengan tingkat kebutuhan tenaga medis COVID-19 berjumlah sekitar 3.690 orang (Wahyudi, N. A., 2020). Jumlah tersebut merupakan salah satu sample data kebutuhan tenaga medis di Jakarta untuk penanganan COVID-19.

Perihal terkait isolasi dirumah masing-masing tersebut dapat terjadi dikarenakan oleh salah satu faktor penyebab yaitu overload nya fasilitas rumah (Hamdi, I., \& Silaban, 2020) dan tempat isolasi yang telah disediakan oleh tenaga medis dan 
Siti Dwi Lazuardi, Akhdan Muhammad Muaz, Dina Fatimatuz Zahroh, Altalariq Pranantha Yudha Airlangga, dan Afyfah Ramadhani Dias Saputri

pemerintah. Tidak menutup kemungkinan, bagi pasien yang melakukan isolasi mandiri tersebut tidak mendapatkan penanganan medis yang intens, dikarenakan jumlah tenaga medis yang tidak sebanding dengan jumlah pasien yang tersebar di wilayah Provinsi DKI Jakarta baik yang dirawat maupun isolasi mandiri dirumah, sehingga dapat menyebabkan peningkatan jumlah kematian akibat COVID-19.

Oleh karena itu, perlu adanya solusi alternatif terkait menanggapi hal tersebut. Solusi alternatif tersebut salah satunya adalah membuat tempat isolasi alternatif untuk menampung pasien positif COVID-19 yang membutuhkan penanganan medis yang intens, terutama di wilayah yang minim lahan. Tempat isolasi alternatif yang dimaksud adalah ruang isolasi apung yang berada di wilayah minim lahan di daerah Jakarta. Ruang isolasi apung yang terbuat dari petikemas bekas yang masih layak pakai dan direncanakan, akan dibangun dengan konsep apung dengan sistem yang hampir sama dengan dermaga apung yaitu menggunakan bahan HDPE dan WPC sebagai tumpuan petikemas agar dapat mengapung. Kelebihan dari WPC adalah daya tahan yang tinggi terhadap benturan, abrasi dan air serta $100 \%$ dapat di daur ulang (Shabrina, 2015). Sedangkan kelebihan pada HDPE adalah fleksibel dan tahan terhadap ombak, $100 \%$ dapat di daur ulang dan dapat mengikuti tinggi pasang surut air laut (Erwanto, 2020).

Ruang isolasi apung didesain sesuai dengan ketentuan dan kriteria ruang isolasi bagi pasien COVID-19. Hal tersebut di gagas untuk membantu melayani masyarakat yang tidak mendapatkan fasilitas rumah sakit atau tempat isolasi yang telah disediakan oleh tenaga medis dan pemerintah karena overload.

\section{Metode Penelitian}

a. Diagram Alir

Di dalam pengerjaan penelitian inovasi ini, terdapat diagram alir pengerjaan, berikut merupakan diagram alir pengerjaan penelitian:

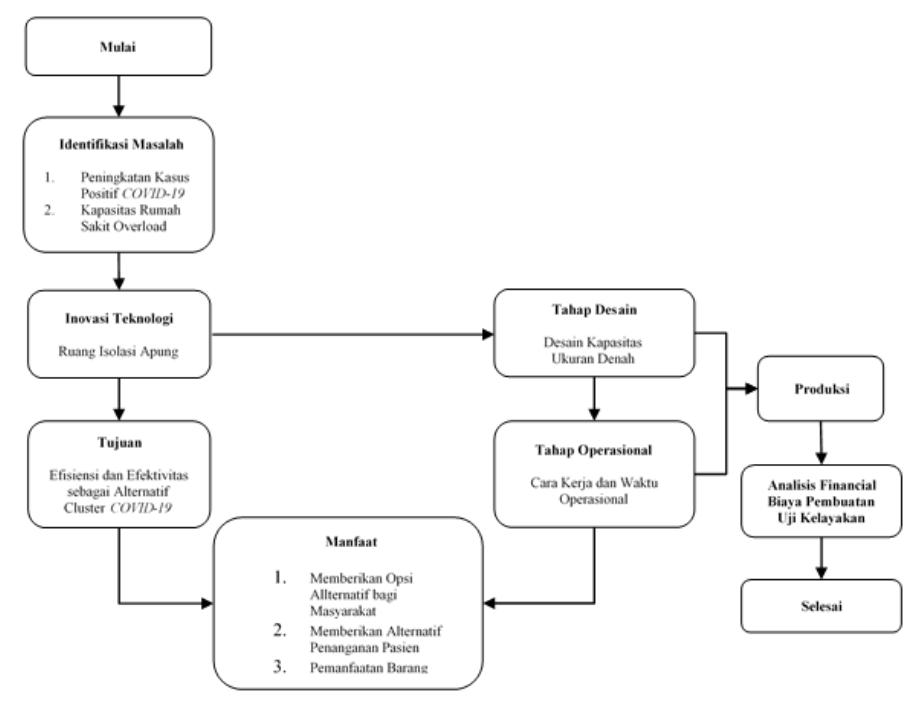

\section{Gambar 4}

Diagram Alir Pengerjaan Penelitian 
Dalam pembuatan inovasi ruang isolasi apung, yang pertama kali dilakukan adalah identifikasi permasalahan, dari tahap pertama ditemukan permasalahan, yaitu adanya peningkatan kasus positif COVID-19 yang mengakibatkan kapasitas rumah sakit rujukan COVID-19 dan ruang isolasi umum menjadi overload. Maka, penelitian ini memberikan solusi alternatif untuk permasalahan tersebut, yaitu inovasi ruang isolasi apung yang bertujuan untuk efisiensi dan efektivitas sebagai alternatif cluster COVID-19. Manfaat dari ruang isolasi apung ini adalah memberikan opsi alternatif bagi masyarakat, memberikan alternatif penanganan pasien, dan pemanfaatan barang bekas (petikemas). Setelah mengetahui tujuan dan manfaat, selanjutnya dilakukan tahap membuat desain ruang isolasi apung, menentukan kapasitas, dan juga ukuran serta denah dari ruang isolasi apung. Setelah tahap desain, maka dilakukan tahap selanjutnya yaitu tahap operasional. Dalam tahap operasional ditentukan sistem kerja dari ruang isolasi apung serta diperhitungkan pula waktu operasional ruang isolasi apung. Setelah itu, dilakukan proses produksi yang dalam hal ini yaitu pembuatan ruang isolasi apung. Selama tahap produksi, dilakukan juga analisis finansial biaya pembuatan ruang isolasi apung. Metode yang digunakan dalam proses analisis finansial biaya adalah CBA (Cost-Benefit Analysis). Setelah analisis finansial biaya dan pembuatan ruang isolasi apung selesai, dilakukan uji kelayakan terhadap inovasi, untuk menguji kelayakan pada penelitian ini, pendekatan yang digunakan adalah dengan menggunakan pendekatan BCR (Benefit Cost Ratio) yaitu metode uji kelayakan dengan membandingkan besarnya biaya dan manfaat yang telah didapat melalui metode CBA. Setelah inovasi ruang isolasi apung dinyatakan layak untuk beroperasi, maka proses produksi selesai dan ruang isolasi apung siap untuk digunakan.

b. Data Penelitian

Di dalam penelitian ini, telah didapatkan beberapa data berupa data sekunder, dikarenakan tidak dapat mendapatkan data yang dilakukan dengan survei secara langsung ke lokasi akibat adanya COVID-19. Berikut data-data yang didapatkan dari proses pengerjaan penelitian:

1. Kondisi Dermaga

Kondisi dermaga sangat diperlukan untuk mengetahui beberapa aspek dari pelabuhan seperti luas kolam pelabuhan, panjang, lebar, serta kedalaman dari alur pelabuhan

2. Luas Bidang Penampang Container

Diperlukan data luas bidang penampang dan kekuatan beban pada Dermaga Apung yang akan dipergunakan untuk penempatan container berukuran 20ft ( $\mathrm{L}=6,0 \mathrm{~m}, \mathrm{~B}=2,4 \mathrm{~m} \mathrm{~T}=2,6 \mathrm{~m})$ (Sinaga, 2011).

3. Fasilitas Ruang Isolasi

Standarisasi ruang isolasi COVID-19 telah diatur oleh Menteri Kesehatan Republik Indonesia lewat Keputusan Kementerian Kesehatan Republik Indonesia Nomor HK.01.07 / Menkes / 413 / 2020 Tentang 
Siti Dwi Lazuardi, Akhdan Muhammad Muaz, Dina Fatimatuz Zahroh, Altalariq Pranantha Yudha Airlangga, dan Afyfah Ramadhani Dias Saputri

Pedoman Pencegahan dan Pengendalian Coronavirus Diseas 2019 (COVID - 19) (Indonesia, M. K. R., 2020).

c. Metode Perhitungan

Pada proses penelitian pembangunan ruang isolasi apung, dalam menghitung besarnya manfaat serta biaya sebagai solusi alternatif pada masalah yang telah dijelaskan sebelumnya adalah dengan menggunakan metode CBA (Cost-Benefit Analysis), yaitu alat bantu untuk membuat keputusan dengan mempertimbangkan biaya dan manfaat secara optimal dengan membandingkan kondisi eksisting dengan kondisi inovasi. Sehingga terdapat tiga analisis yang muncul pada penelitian ini, yaitu analisis perbandingan kondisi, analisis manfaat dan analisis biaya. Sedangkan untuk menguji kelayakan pada penelitian ini, pendekatan yang digunakan adalah dengan menggunakan pendekatan BCR (Benefit Cost Ratio) yaitu metode uji kelayakan dengan membandingkan besarnya biaya dan manfaat yang telah didapat melalui metode CBA yang memiliki persamaan sebagai berikut ini :

$$
\text { Benefit }- \text { Cost Ratio }=\frac{\text { PV Benefit }}{\text { PV Cost }}=\frac{\mathrm{B}}{\mathrm{C}}
$$

Kelayakan pada suatu proyek atau penelitian dapat dilihat dari nilai BCR yang dihasilkan. Ketika nilai BCR yang dihasikan adalah $\mathrm{BCR} \geq 1$, maka benefit dari proyek atau penelitian tersebut lebih besar dari pengorbanan (biaya) yang dikeluarkan, sehingga proyek tersebut dapat diterima atau layak. Tetapi ketika nilai $\mathrm{BCR}<1$, maka benefit dari proyek tersebut lebih kecil dari pengorbanannya (biaya), sehingga proyek tersebut dikatakan tidak layak.

\section{Hasil dan Pembahasan}

a. Inovasi

Inovasi pada penelitian ini adalah suatu solusi alternatif bagi pasien positif COVID-19 yang harus menjalankan karantina mandiri di rumah dikarenakan overloadnya rumah sakit dan ruang isolasi umum. Solusi alternatif tersebut berupa ruang isolasi apung yang akan beroperasi di Pelabuhan Tanjung Priok, Jakarta, Indonesia. Inovasi tersebut memanfaatkan container bekas yang sudah tidak digunakan kembali, kemudian dimodifikasi menjadi suatu ruangan isolasi. Dengan bantuan HDPE (High-Density Polyethylene) dan WPC (Wood Plastick Composite) sebagai dermaga apung, agar container tersebut dapat mengapung diatas air. 
b. Desain Modifikasi Container menjadi Ruang Isolasi Apung
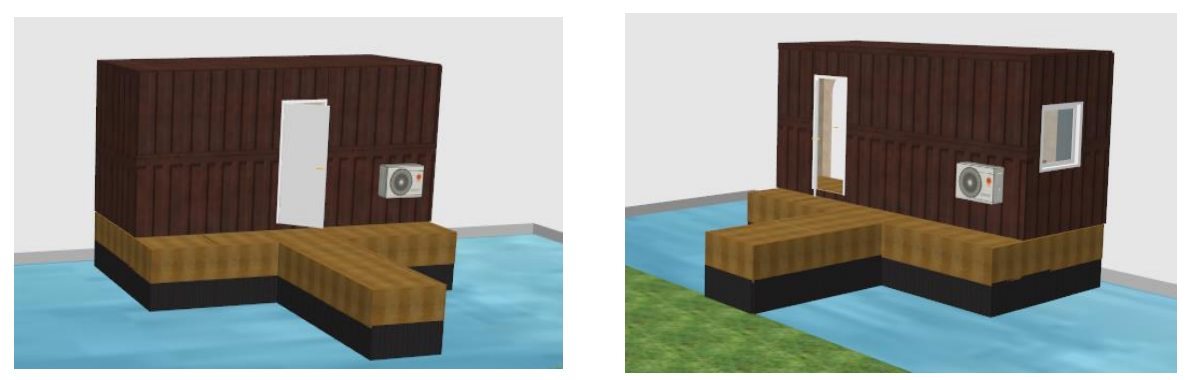

\section{Gambar 5 \\ Desain Ruang Isolasi Apung}

Dengan desain ruang isolasi apung seperti yang tertera pada gambar 5, ruang isolasi apung tersebut memiliki kapasitas pasien pada satu ruangan isolasi yaitu berjumlah dua orang pasien, dengan jangka waktu penggunaan ruang isolasi selama tujuh hari bagi tiap pasien yang dirawat. Ruang isolasi apung memiliki total kapasitas tampung bagi pasien positif COVID-19 yang tidak mendapatkan fasilitas rawat inap di rumah sakit rujukan COVID-19 atau ruang isolasi umum yaitu berjumlah 124 pasien, dengan total ruang isolasi apung Jakarta adalah 62 ruang isolasi apung.
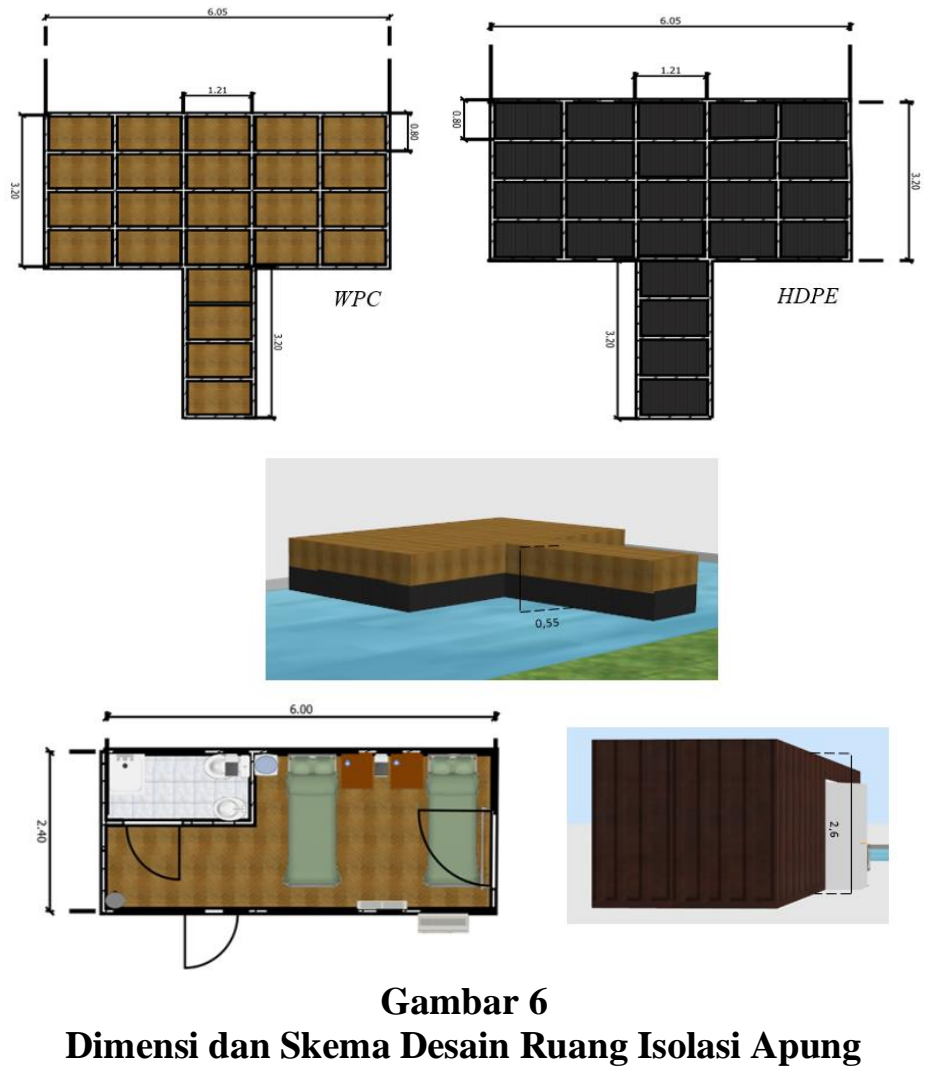
Siti Dwi Lazuardi, Akhdan Muhammad Muaz, Dina Fatimatuz Zahroh, Altalariq Pranantha Yudha Airlangga, dan Afyfah Ramadhani Dias Saputri

Ruang isolasi apung memiliki dimensi ukuran seperti ukuran container 20 feet yaitu panjang 6 meter, lebar 2,4 meter dan tinggi 2,6 meter. Skema ruang isolasi apung tertera pada gambar 6 yang memiliki skema ruangan dengan terdiri dari 2 tempat tidur untuk pasien, 1 kamar mandi dalam beserta wastafel, dispenser, serta dilengkapi dengan 1 air conditioner $(A C), 1$ jendela, 1 tempat sampah, 1 exhaust dan 2 lemari pakaian.

c. Sistem Kerja dan Waktu Operasional Ruang Isolasi Apung

Sistem kerja pada ruang isolasi apung ini bersifat tidak moveable. Walaupun menggunakan HDPE sebagai bahan untuk membuat dermaga apung pada ruang isolasi, namun sistem kerja ruang isolasi apung ini akan tetap berada di wilayah pelabuhan dan tidak berpindah tempat. sistem tersebut diterapkan untuk mempermudah akses operasional dalam penanganan pasien positif COVID-19 yang dimungkinkan akan bekerja sama dengan rumah sakit isolasi COVID-19 terdekat dalam hal pemenuhan kebutuhan tertentu seperti persediaan obat atau peralatan lain sebagai penunjang penanganan pasien.

Namun setelah pandemi COVID-19 berakhir, sistem ruang isolasi apung ini dapat dialih fungsikan menjadi sistem rumah sakit apung yang bersifat moveable atau dapat berpindah-pindah tempat. Sehingga dapat melayani kesehatan masyarakat di beberapa wilayah. Namun, sebelum beroperasi sebagai rumah sakit apung, tentu diperlukan adanya pertimbangan mengenai kemungkinan fasilitas yang ada di ruang isolasi apung, dapat tetap digunakan atau harus dirubah dengan fasilitas yang baru. Tentu juga perlu diadakan sterilisasi dengan cara menyemprotkan disinfektan di ruangan container yang ada di ruang isolasi apung.

Untuk total waktu operasional ruang isolasi apung adalah 24 jam atau nonstop. Waktu operasional tersebut berlaku ketika ruangan isolasi terisi oleh pasien. Tetapi, ketika ruangan tidak terisi oleh pasien atau kosong, maka tidak ada waktu operasional pada ruang isolasi apung ini.

d. Analisis Perbandingan Kondisi

Terdapat analisis perbandingan dari kondisi masyarakat yang harus melakukan isolasi mandiri sebelum dan setelah adanya inovasi ini, yang ditinjau dari perbandingan kondisi dalam segi penanganan dan pemantauan pasien serta dari segi kepatuhan pasien dalam mengikuti protokol kesehatan COVID-19. Berikut merupakan analisis perbandingan kondisi tersebut:

Tabel 1

Analisis Perbandingan Kondisi dari Segi Penanganan dan Pemantauan Pasien

\begin{tabular}{ccc}
\hline Keterangan & Kondisi Eksisting & Kondisi Inovasi \\
\hline Penanganan dan & Tidak Intens dan & Intens dan dapat \\
Pemantauan dari Tenaga & Berkala & dilakukan selama 24 \\
Medis & jam \\
\hline
\end{tabular}

Terdapat perbandingan kondisi pada segi penanganan dan pemantauan pasien positif COVID-19 dari sebelum dan setelah adanya inovasi. Beberapa pasien 
mengeluhkan buruknya melakukan isolasi dirumah, salah satu alasannya yaitu kurangnya pemantauan dan penanganan secara intens dari tenaga medis, dengan begitu, tidak menutup kemungkinan akan terjadinya cluster rumah tangga di tempat tinggal pasien yang menjalankan isolasi mandiri dirumah masing-masing (Kompas.com, 2020) dikarenakan masih berhubungan erat dengan orang lain baik dalam berkomunikasi dan beraktivitas diluar dengan keluarga, teman hingga tetangga (Setiawan, 2020).

Tabel 2

Analisis Perbandingan Kondisi dari Segi Kepatuhan Pasien

\begin{tabular}{ccc}
\hline Keterangan & Kondisi Eksisting & Kondisi Inovasi \\
\hline $\begin{array}{c}\text { Kepatuhan terhadap } \\
\text { Protokol Kesehatan } \\
\text { COVID-19 }\end{array}$ & Tidak 100\% Patuh & $100 \%$ Patuh \\
\hline
\end{tabular}

Karena tidak intensnya penanganan dan pemantauan, menyebabkan terdapatnya beberapa pasien yang tidak melaksanakan protokol kesehatan dalam menjalani masa isolasinya, baik disengaja maupun tidak, contohnya adalah, mengharuskan diri sendiri untuk keluar dalam membeli kebutuhan sehari-hari dikarenakan sedang menjalani karantina mandiri di kos (Kompas.com, 2020). Dengan adanya ruang isolasi alternatif, pasien dapat menempati fasilitas tersebut dengan pastinya mematuhi protokol kesehatan COVID-19 dikarenakan juga terdapat pemantauan dan penanganan intensif dari para tenaga medis dalam menjaga kepatuhan tersebut.

Tabel 3

Pros dan Cons Inovasi Ruang Isolasi Apung

\begin{tabular}{llll}
\hline No & \multicolumn{1}{c}{ Pros } & \multicolumn{1}{c}{ Cons } \\
\hline Mengurangi angka pasien positif & $\begin{array}{l}\text { COVID-19 yang melakukan isolasi } \\
\text { mandiri \& penyebaran cluster baru } \\
\text { di lingkungan masyarakat }\end{array}$ & $\begin{array}{l}\text { Menambah jumlah anggaran biaya } \\
\text { penanganan COVID-19 }\end{array}$ \\
\hline $\begin{array}{l}\text { Proses penyembuhan semakin cepat } \\
\text { dengan penanganan medis yang } \\
\text { intens }\end{array}$ & $\begin{array}{l}\text { Jumlah ruangan isolasi yang terbatas karena } \\
\text { terletak di pelabuhan dan operasional harus } \\
\text { selalu dikoordinasikan dengan otoritas } \\
\text { pelabuhan }\end{array}$ \\
\hline $\begin{array}{l}\text { Menambah lowongan pekerjaan } \\
\text { bagi tenaga kesehatan }\end{array}$ & $\begin{array}{l}\text { Hanya dapat menampung pasien dengan } \\
\text { jumlah terbatas, dikarenakan jumlah ruang } \\
\text { isolasi yang terbatas karena terletak di area } \\
\text { pelabuhan }\end{array}$ \\
\hline
\end{tabular}

Selain adanya perbandingan kondisi eksisting dengan inovasi dari segi penanganan dan pemantauan serta dari segi kepatuhan, terdapat pula pros dan cons terhadap kondisi eksisting dengan kondisi setelah adanya inovasi. Pros dan cons tersebut tertera seperti pada tabel 3.

e. Analisis Manfaat 
Siti Dwi Lazuardi, Akhdan Muhammad Muaz, Dina Fatimatuz Zahroh, Altalariq Pranantha Yudha Airlangga, dan Afyfah Ramadhani Dias Saputri

Sebelum adanya ruang isolasi apung, para pasien COVID-19 banyak yang harus melakukan isolasi mandiri dikarenakan kapasitas rumah sakit rujukan pasien COVID-19 yang penuh. Dengan melakukan isolasi mandiri, pasien hanya dipantau secara berkala dengan tidak langsung ditangani oleh tenaga kesehatan. Oleh karena itu, tingkat kesembuhan pasien positif COVID-19 yang melakukan isolasi mandiri dinilai rendah. Dengan adanya ruang isolasi apung, akan menambah tempat isolasi rujukan baru bagi pasien positif COVID-19, sehingga akan sangat membantu dalam penanganan pasien positif COVID-19. Pasien akan mendapat pengawasan dan penanganan secara intensif dari tenaga kesehatan sehingga tingkat kesembuhan pasien dapat meningkat dalam waktu singkat.

Tabel 4

Hasil Perbandingan Pasien Dirawat dan Isolasi Mandiri Sebelum dan Setelah Inovasi

\begin{tabular}{cccccc}
\hline \multicolumn{3}{c}{ Sebelum } & \multicolumn{3}{c}{ Setelah } \\
\hline Isolasi Mandiri & $:$ & Dirawat & Isolasi Mandiri & $:$ & Dirawat \\
\hline $80 \%$ & $:$ & $20 \%$ & $45 \%$ & $:$ & $55 \%$ \\
\hline 4 & $:$ & 1 & 5 & $:$ & 6 \\
\hline
\end{tabular}

Pada tabel 4 terlihat bahwa sebelum adanya inovasi ini, perbandingan jumlah pasien isolasi mandiri dengan pasien yang dirawat memiliki perbandingan yang cukup jauh, yaitu 4:1 dengan keterangan 4 isolasi mandiri dan 1 yang dirawat. Setelah adanya inovasi, perbandingan pasien isolasi mandiri dengan yang dirawat yang memiliki jumlah yang hampir sama yaitu 5:6 dengan keterangan yaitu 5 untuk isolasi mandiri dan 6 untuk yang dirawat yang berarti, jumlah isolasi mandiri lebih kecil dari yang dirawat.

f. Analisis Biaya

Berikut merupakan biaya yang muncul dari inovasi Ruang Isolasi Apung:

Tabel 5

Biaya Pengadaan Ruang Isolasi Apung

\begin{tabular}{|c|c|c|c|}
\hline Item & Biaya & Jumlah & Biaya \\
\hline Capital Cost & Rp 178.787.480 & 62 & Rp 11.084.823.760 \\
\hline Operasional Cost & $\operatorname{Rp} 204.671 .324 .261$ & 1 & $\mathrm{Rp} 204.671 .324 .261$ \\
\hline Fixed Cost & Rp 997.634.138 & 1 & Rp 997.634.138 \\
\hline Wages Cost & Rp 550.000.000 & 12 & $\operatorname{Rp~6.600.000.000~}$ \\
\hline
\end{tabular}

Biaya-biaya tersebut dihitung sesuai dengan jumlah container yang akan disediakan yaitu 62 container beserta dermaga apungnya yang akan dipergunakan sebagai ruang isolasi apung. Biaya pertama yang dikeluarkan adalah pembiayaan terkait pengadaan ruang isolasi apung dimana mencakup dermaga apung dan container dengan fasilitas didalamnya sesuai dengan standarisasi yang dikeluarkan oleh Kementerian Kesehatan mengenai Pedoman Teknis Ruang Isolasi. Biaya operasional dari inovasi ini meliputi biaya penggunaan listrik, biaya kebutuhan air bersih, biaya konsumsi pasien, biaya kebutuhan Alat Pelindung Diri (APD), 
kebutuhan penanganan pasien, kebutuhan sterilisasi ruangan, biaya operational cost dilakukan pertahun. Terdapat 3 jenis pembiayaan fixed cost pada inovasi ini diantaranya yaitu, Biaya perawatan, biaya asuransi, dan biaya perpajakan yang muncul selama satu tahun sekali, Adapun biaya yang muncul berupa biaya gaji dari tenaga medis meliputi dokter, perawat, dan petugas Kesehatan penunjang lainnya yang muncul per bulan.

g. Rasio Manfaat Biaya

Tabel 6

Analisis Antara Manfaat dan Biaya Dari Penggunaan Ruang Isolasi Container Apung

\begin{tabular}{ll}
\hline \multicolumn{1}{c}{ Rincian } & \multicolumn{1}{c}{ Kondisi Inovasi } \\
\hline PV Biaya Ruang Isolasi Apung & Rp 939.666.809.915,68 \\
\hline PV Manfaat & Rp 959.787.088.541 \\
\hline BCR = (PVmanfaat / PVbiaya) & 1,02 \\
\hline NPV & Rp 20.120.278.625,47 \\
\hline Status Kelayakan & LAYAK \\
\hline
\end{tabular}

Berdasarkan pada perhitungan Cost-Benefit Analysis yang dilakukan terhadap inovasi ruang isolasi container dermaga apung dengan perhitungan time frame selama 5 tahun. Inovasi ini memiliki rasio manfaat sebesar 1,02 dan nilai NPV sebesar Rp. 20.120.278.625,47 dimana angka tersebut mengartikan bahwa inovasi ini layak untuk dijalankan karena BCR > 1, dan NPV > 1 .

\section{Kesimpulan}

Dari hasil proses pengerjaan penelitian Inovasi Ruang Isolasi Apung yang telah diuraikan sebelumnya, dapat ditarik beberapa kesimpulan, sebagai berikut ini: (a) Tingginya jumlah kenaikan pasien positif COVID-19 menyebabkan overloadnya rumah sakit rujukan COVID-19 dan fasilitas ruang isolasi dari pemerintah, sehingga meningkatnya jumlah pasien positif COVID-19 yang harus menjalankan isolasi mandiri di rumah masing-masing dan tidak mendapatkan fasilitas yang seharusnya didapat oleh pasien positif COVID-19. (b) Rencana desain inovasi adalah petikemas yang sudah tidak digunakan kembali dengan dilengkapi oleh dermaga apung berbahan HDPE dan WPC yang memiliki ukuran 6 mx 2,4 m x 2,6 m dengan kapasitas satu ruangan adalah dua orang pasien dan dilengkapi dengan toilet dalam beserta lemari pakaian, air conditioner (AC) serta wastafel. (c) Ruang Isolasi Apung memiiki sistem kerja yang tidak moveable, untuk mempermudah akses operasional dalam penanganan pasien positif COVID-19. Ruang Isolasi Apung memiliki waktu operasional yaitu 24 Jam (ketika terdapat pasien). (d) Total biaya pembangunan ruang isolasi apung yang dilengkapi oleh dermaga apung berbahan HDPE dan WPC adalah sebesar Rp 178.787.480 meter persegi. Berdasarkan pada perhitungan dengan metode CBA yang dilakukan terhadap inovasi ruang isolasi apung dengan perhitungan time frame selama 5 tahun. Inovasi ini memiliki rasio manfaat sebesar 1,02 dan nilai NPV sebesar Rp. 20.120.278.625,47 dengan status kelayakan = Layak, yaitu BCR $>1$, dan NPV>1. 
Siti Dwi Lazuardi, Akhdan Muhammad Muaz, Dina Fatimatuz Zahroh, Altalariq Pranantha Yudha Airlangga, dan Afyfah Ramadhani Dias Saputri

\section{BIBLIOGRAFI}

Corona.jakarta.go.id. Data Pemantauan Covid-19. (2020).

Databoks. (2018). Berapa Jumlah Penduduk Jakarta. Retrieved from https://databoks.katadata.co.id/datapublish/2018/01/24/berapa-jumlah-penduduk ja jakarta\#: :text=Jumlah Penduduk DKI Jakarta (1961-2017)\&text=Kemudian meningkat menjadi $10 \% 2 \mathrm{C} 28$, atau 11 orang per jam\%0A[Accessed 26 November 2020]

Databoks. (2019). Proyeksi Jumlah Penduduk DKI Jakarta 2020. Retrieved from https://databoks.katadata.co.id/datapublish/2019/12/07/jumlah-penduduk-dki jakarta-2020\#: :text=Survei penduduk antar sensus (SUPAS,yang sebanyak 10

Databoks \& Jayani, D. H. (2019). Jumlah Penduduk DKI Jakarta 2019 Mencapai 10,5 Juta Jiwa. Retrieved from https://databoks.katadata.co.id/datapublish/2019/09/10/ jumlah-penduduk-dki-jakarta-2019-mencapai-105-juta-jiwa\%0A[Accessed 26 November 2020].

Erwanto, R. (2020). Inovasi Kubus HDPE untuk Pembuatan Dermaga Apung. Kompasiana.Com.

Hamdi, I., \& Silaban, M. W. (2020). Rumah Sakit Rujukan Overload, Pemerintah Diminta Serius Tekan Penularan Covid-19. Retrieved from https://metro.tempo.co/read/1374996/rumah-sakit-rujukan-overload-pemerintahdiminta-serius-tekan-penularan-covid-19/full\&view=ok

Indonesia, M. K. R. (2020). Keputusan Menteri Kesehatan Republik Indonesia.

kemkes.go.id. (2020). Informasi SDM Kesehatan Nasional. Retrieved from http://bppsdmk.kemkes.go.id/info_sdmk/info/index?rumpun=1

Kompas.com. (2020). Ini Tata Cara Pemilihan di TPS Saat Pilkada di Masa Pandemi Covid-19.

Ningsih, Safena, Yandri, Hengki, Sasferi, Nuzmi, \& Juliawati, Dosi. (2020). An Analysis of Junior High School Students' Learning Stress Levels during the COVID-19 Outbreak: Review of Gender Differences. Psychocentrum Review, 2(2), 69-76.

Sadikin, Ali, \& Hamidah, Afreni. (2020). Pembelajaran Daring di Tengah Wabah Covid-19:(Online Learning in the Middle of the Covid-19 Pandemic). Biodik, 6(2), 214-224. 
Setiawan, R. (2020). Baik-Buruk Penghapusan Isolasi Mandiri Penderita COVID-19 ala Anies. Retrieved from https://tirto.id/baik-buruk-penghapusan-isolasi-mandiripenderita-covid-19-ala-anies-f3sP

Shabrina, A. (2015). Mengenal Wood Plastic Composite [WPC]. Arsitag.Com.

Sinaga. (2011). Port and Harbour Structure Services. Retrieved from berthing.wordpress.com:https://berthing.wordpress.com/2011/02/03/ukurandimens i-standart-containerpeti-kemas/

Wahyudi, N. A. (2020). Tangani Corona, DKI Terima 1.190 Tenaga Kesehatan Tambahan. 